\title{
Inhibitory Effect of Furosemide on Non- Selective Voltage-Independent Cation Channels in Human Erythrocytes
}

\author{
Yuliya V. Kucherenko ${ }^{\mathrm{a}, \mathrm{b}} \quad$ Florian Lang ${ }^{\mathrm{a}}$ \\ ${ }^{a}$ Department of Physiology Institute I, Eberhard-Karls Universität Tübingen, ${ }^{b}$ Institute for Problems of \\ Cryobiology and Cryomedicine of the Ukrainian National Academy of Sciences, Kharkov
}

\section{Key Words}

Patch-clamp • Cation channels - ATP-depletion • Oxidation • Phosphatidylserine exposure • Eryptosis $•$ Suicidal erythrocyte death

\begin{abstract}
Background: Furosemide, a loop diuretic inhibiting the renal tubular $\mathrm{Na}^{+}, \mathrm{K}^{+}, 2 \mathrm{Cl}^{-}$cotransporter, has been shown to decrease cytosolic $\mathrm{Ca}^{2+}$ concentration $\left(\left[\mathrm{Ca}^{2+}\right]_{i}\right)$ in platelets and erythrocytes. $\left[\mathrm{Ca}^{2+}\right]_{\mathrm{i}}$ in erythrocytes is a function of $\mathrm{Ca}^{2+}$ permeable cation channels. Activation of those channels e.g. by energy depletion or oxidative stress leads to increase of $\left[\mathrm{Ca}^{2+}\right]_{i}$, which in turn triggers eryptosis, a suicidal erythrocyte death characterized by cell membrane scrambling. The present study was performed to explore whether furosemide influences the cation channels and thus influences eryptosis. Methods: Cation channel activity was determined by whole-cell patch clamp, $\left[\mathrm{Ca}^{2+}\right]_{i}$ utilizing Fluo3 fluorescence and annexin $\mathrm{V}$ binding to estimate cell membrane scrambling with phosphatidylserine exposure. Results: A 45 min exposure to furosemide $(10$ and $100 \mu \mathrm{M})$ slightly, but significantly decreased cation channel activity and $\left[\mathrm{Ca}^{2+}\right]_{i}$ in human erythrocytes drawn from healthy individuals. ATP-depletion (> 3 hours, $+37^{\circ} \mathrm{C}, 6 \mathrm{mM}$ ionosine and $6 \mathrm{mM}$ iodoacetic acid) enhanced the non-selective cation channel activity, increased $\left[\mathrm{Ca}^{2+}\right]_{i}$ and triggered cell membrane scrambling, effects significantly blunted by furosemide $(10-100 \mu \mathrm{M})$. Oxidative stress by exposure to tert-butylhydroperoxide $(0.1-$ $1 \mathrm{mM})$ similarly enhanced the non-selective cation channels activity, increased $\left[\mathrm{Ca}^{2+}\right]_{i}$ and triggered cell membrane scrambling, effects again significantly blunted by furosemide (10 - $100 \mu \mathrm{M}$ ). Conclusions: The present study shows for the first time that the loop diuretic furosemide applied at micromolar concentrations $(10-100 \mu \mathrm{M})$ inhibits non-selective cation channel activity in and eryptosis of human erythrocytes.
\end{abstract}




\section{Introduction}

Furosemide, a sulphonamide derivative, is clinically widely used as a high ceiling loop diuretic [1]. The diuretic effect of furosemide is accomplished by inhibition of the $\mathrm{Na}^{+}, \mathrm{K}^{+}, 2 \mathrm{Cl}^{-}$cotransporter in the thick ascending limb [2-6]. Further effects of furosemide include non-competitive inhibition of GABA-A receptor subtypes [1, 7] as well as influence of protein kinase B PKB/Akt [8], mitogen activated protein kinase MAP [9] and cAMPphosphodiesterase [10]. Furosemide further modifies $\mathrm{Na}^{+} / \mathrm{K}^{+}$-ATPase activity by stimulating the $\mathrm{Na}^{+} / \mathrm{H}^{+}$-exchanger [11]. At high concentrations furosemide inhibits platelet aggregation [12], water flux via aquaporin-1 water channels [13], adenosine transport in erythrocytes [14], postoperative pain in rats [15] and the new permeability pathways (NPP) induced by the malaria pathogens plasmodia in parasitized erythrocytes [16-18]. Moreover, furosemide may counteract apoptosis [5, 8]. Furosemide infusion attenuated ischemia-induced apoptosis and associated gene transcription [8], inhibited Bax translocation to mitochondria [19, 20] and modified RAF/MEK/ERK phosphorylation in Balb/c 3T3 fibroblasts [9]. Exposure of human peripheral blood mononuclear cells to $5 \mathrm{mM}$ furosemide decreased the levels of proinflammatory cytokines TNF-alpha and IL-6, mimicking the effect of hydrocortisone [21]. Even higher concentrations of furosemide $(10 \mathrm{mM})$ are cytotoxic [21]. In vivo fuoremide treatment leads to upregulation of renin [22]. A parallel increase of ubiquitous, membranebound angiotensin-converting enzyme [23] may result in enhanced angiotensin II production, with subsequent activation of membrane-bound NADPH-oxidase, increased $\mathrm{O}_{2}$ - production, inactivation of endothelial $\mathrm{NO}$, increase in $\mathrm{ONOO}^{-}$, and thus inflammation [24]. Accordingly, high concentrations of furosemide may promote inflammation.

Loop diuretics including furosemide decrease intracellular free calcium concentration $\left(\left[\mathrm{Ca}^{2+}\right]_{\mathrm{i}}\right)$ in platelets and erythrocytes from patients with hypertension [25-27]. The lowering effect of loop diuretics on $\left[\mathrm{Ca}^{2+}\right]_{i}$ is considered to result from its effect on the $\mathrm{Na}^{+}, \mathrm{K}^{+}, 2 \mathrm{Cl}^{-}$ cotransporter activity. The carrier increases cytosolic $\mathrm{Cl}^{-}$activity above thermodynamic equilibrium across the cell membrane leading to an outwardly directed electrochemical gradient, which in turn fosters $\mathrm{Cl}^{-}$exit and thus depolarization. The depolarisation increases $\left[\mathrm{Ca}^{2+}\right]_{\mathrm{i}}$ by activating voltage-gated $\mathrm{Ca}^{2+}$ channels [4]. Diuretic treatment may further enhance $\left[\mathrm{Ca}^{2+}\right]_{\mathrm{i}}$ by modifying the gradient for the $\mathrm{Na}^{+} / \mathrm{Ca}^{2+}$ - exchanger [28].

In human erythrocytes increases of $\left[\mathrm{Ca}^{2+}\right]_{i}$ may stimulate suicidal cell death or eryptosis with cell membrane scrambling and subsequent phosphatidylserine (PS) exposure at the cell surface $[29,30]$. Eryptotic cells are rapidly eliminated from circulating blood by macrophages $[29,30]$. Eryptosis is triggered by a wide variety of clinical conditions [24, 30-40], chemicals [30, 41-53], energy depletion [54] and oxidative stress [55, 56]. Erythrocytes are lacking intracellular calcium stores (mitochondria and sarcoplasmic reticulum) and an increase in $\left[\mathrm{Ca}^{2+}\right]_{\mathrm{i}}$ may result from activation of $\mathrm{Ca}^{2+}$-permeable cation channels.

According to electrophysiological studies two types of non-selective cation channels permeable for $\mathrm{Ca}^{2+}$ are expressed in human erythrocytes. The voltage-gated channel, coupled to an acetylcholine receptor [57-59] and the voltage-independent $\mathrm{Cl}^{-}$-sensitive cation channels that can be activated by oxidation, osmotic shock and energy depletion [60]. The voltage-independent channels were shown to be partially related to TRPC6 channels [61]. Moreover, erythrocytes may express NMDA receptors in the rat [62] and AMPA receptors in man [31]. The presence of subtypes of voltage-dependent $\mathrm{Ca}^{2+}$ channels was demonstrated by Western blot analysis in age-fractionated erythrocytes [63] but has not been detected by patch-clamp.

The present study explored whether furosemide at therapeutic serum concentrations $(6-30 \mu \mathrm{M}[64])$ and higher concentrations $(100 \mu \mathrm{M})$ used for inhibition of new permeability pathways (NPP) in malaria infected erythrocytes [16-18] influences $\mathrm{Ca}^{2+}$ permeable cation channels, $\left[\mathrm{Ca}^{2+}\right]_{\mathrm{i}}$ and cell membrane scrambling in human erythrocytes. It is indeed shown for the first time that the loop diuretic furosemide applied at micromolar concentrations $(10-100 \mu \mathrm{M})$ decreases cation channel activity, decreases $\left[\mathrm{Ca}^{2+}\right]_{\mathrm{i}}$ and protects against cell membrane scrambling following energy depletion and oxidative stress. 


\section{Materials and Methods}

\section{Erythrocytes}

The experiments were carried out with banked erythrocyte concentrates provided by the blood bank of the University of Tübingen. Erythrocytes were washed twice $\left(1200 \mathrm{~g}, 5 \mathrm{~min}, 22^{\circ} \mathrm{C}\right)$ in physiological saline buffered with $10 \mathrm{mM}$ HEPES ( $\mathrm{pH}$ 7.4). Metabolically depleted cells were obtained according to the method of Lew [65] by incubation of control cells ( $>3$ hours, $+37^{\circ} \mathrm{C}$ ) in the ATP-depleting medium consisting of (mM): $140 \mathrm{NaCl}, 5 \mathrm{KCl}, 10 \mathrm{HEPES}, 6$ iodoacetic acid, and 6 inosine. Furosemide (10, 30 and $100 \mu \mathrm{M}$ final concentrations) was added as a component of ATP-depleting medium. Oxidative stress was induced by addition of $0.1,0.3$ and $1 \mathrm{mM}$ tert-butyl-hydroperoxide (t-BHP) to the cells in the absence or presence of furosemide $(10,30$ and $100 \mu \mathrm{M})$.

\section{Electrophysiology}

Whole-cell patch clamp recordings were performed at room temperature. The patch electrodes were made of borosilicate glass capillaries (150 TF-10, Clark Medical Instruments) using a horizontal DMZ puller (Zeitz). Pipettes with high resistance from 17 to $20 \mathrm{MOhm}$ were connected via an Ag-AgCl wire to the headstage of an EPC 9 patch-clamp amplifier (HEKA). Data acquisition and data analysis were controlled by a computer equipped with an ITC 16 interface (Instrutech) and by using Pulse software (HEKA). For current measurements, erythrocytes were held at a holding potential $\left(\mathrm{V}_{\mathrm{h}}\right)$ of $-10 \mathrm{mV}$ and $200 \mathrm{~ms}$ pulses from -100 to $+100 \mathrm{mV}$ were applied in increments of $+20 \mathrm{mV}$. The currents were analyzed by averaging the current values measured between 90 and $190 \mathrm{~ms}$ of each square pulse (current-voltage relationship). The applied voltages refer to the cytoplasmic face of the membrane with respect to the extracellular space. The offset potentials between both electrodes were zeroed before sealing. The liquid junction potentials between bath and pipette solutions, and between the bath solutions and the salt bridge (filled with $\mathrm{NaCl}$ bath solution) were calculated according to Barry and Lynch [66]. Data were corrected for liquid junction potentials. Recordings were obtained after reaching >10 G $\Omega$ seal in on-cell configuration.

The pipette solution consisted of (in mM): 125 Na-gluconate, $10 \mathrm{NaCl}, 1 \mathrm{MgCl}_{2}, 1 \mathrm{MgATP}, 1$ EGTA, 10 HEPES/NaOH (pH 7.4). The $\mathrm{NaCl}$ Ringer bath solution contained (in mM): $145 \mathrm{NaCl}, 5 \mathrm{KCl}, 2 \mathrm{MgCl}_{2}, 1$ $\mathrm{CaCl}_{2}, 5$ glucose, $10 \mathrm{HEPES} / \mathrm{NaOH}$ ( $\mathrm{pH}$ 7.4). In experiments, where $\mathrm{Cl}^{-}$was substituted with gluconate, the solution contained (in mM): 150 Na-gluconate and $10 \mathrm{HEPES} / \mathrm{NaOH}$ (pH 7.4). The NMDG-Cl, and $\mathrm{CaCl}_{2}$ bath solutions contained (in mM): $180 \mathrm{NMDG}$ (titrated with $\mathrm{HCl}$ to $\mathrm{pH} 7.4$ ) or $100 \mathrm{CaCl}_{2}$ (titrated with $\mathrm{CaOH}_{2}$ to pH 7.4), 10 HEPES. Reagents were obtained from Sigma (Germany) and were of the highest grade available. All bath solutions used in whole-cell patch-clamp experiments on ATP-depleted furosemide-pretreated cells contained furosemide $(30 \mu \mathrm{M}$ and $100 \mu \mathrm{M})$. In the experiments with acutely oxidized cells $\left(20 \mathrm{~min}, 22^{\circ} \mathrm{C}, 1\right.$ $\mathrm{mM}$ t-BHP) furosemide $(100 \mu \mathrm{M})$ was added as a component of the $\mathrm{NaCl}$ Ringer bath solution.

\section{Intracellular $\mathrm{Ca}^{2+}$}

Experiments were performed with ATP-depleted, t-BHP oxidized or with erythrocytes incubated for 45 minutes in the $\mathrm{NaCl}$-containing Ringer bath in the presence or absence of furosemide $(10,30$ and $100 \mu \mathrm{M})$. Erythrocytes ( $0.4 \%$ suspension) were washed in the appropriate media (with or without 10,30 and $100 \mu \mathrm{M}$ furosemide) containing $5 \mathrm{mM} \mathrm{CaCl}_{2}$ and loaded with $2 \mu \mathrm{M}$ Fluo-3/AM (Calbiochem, Bad Soden, Germany). The cells were incubated at $37^{\circ} \mathrm{C}$ for $20 \mathrm{~min}$, washed once and resuspended in $5 \mathrm{mM} \mathrm{Ca}^{2+}$-containing Ringer/ ATP-depleting bath media (with or without 10, 30 and $100 \mu \mathrm{M}$ furosemide) and subsequently analyzed in fluorescence channel FL-1 in FACS analysis.

Phosphatidylserine exposure

Cells ( $0.4 \%$ suspension) were prepared as described above and stained with annexin V-Fluos (Roche, Mannheim, Germany) at a 1:50 dilution in $5 \mathrm{mM} \mathrm{Ca}^{2+}$-containing Ringer/ATP depleting bath media in the presence or absence of 10,30 and $100 \mu \mathrm{M}$ furosemide. After $20 \mathrm{~min}$, samples were washed once and resuspended in $5 \mathrm{mM} \mathrm{Ca}^{2+}$-containing Ringer/ATP depleting media (with or without 10, 30 and $100 \mu \mathrm{M}$ furosemide) and measured by flow cytometric analysis (FACS-Calibur from Becton Dickinson; Heidelberg, Germany). Annexin V-fluorescence intensity was measured in fluorescence channel FL-1 with an excitation wavelength of $488 \mathrm{~nm}$ and an emission wavelength of $530 \mathrm{~nm}$. 


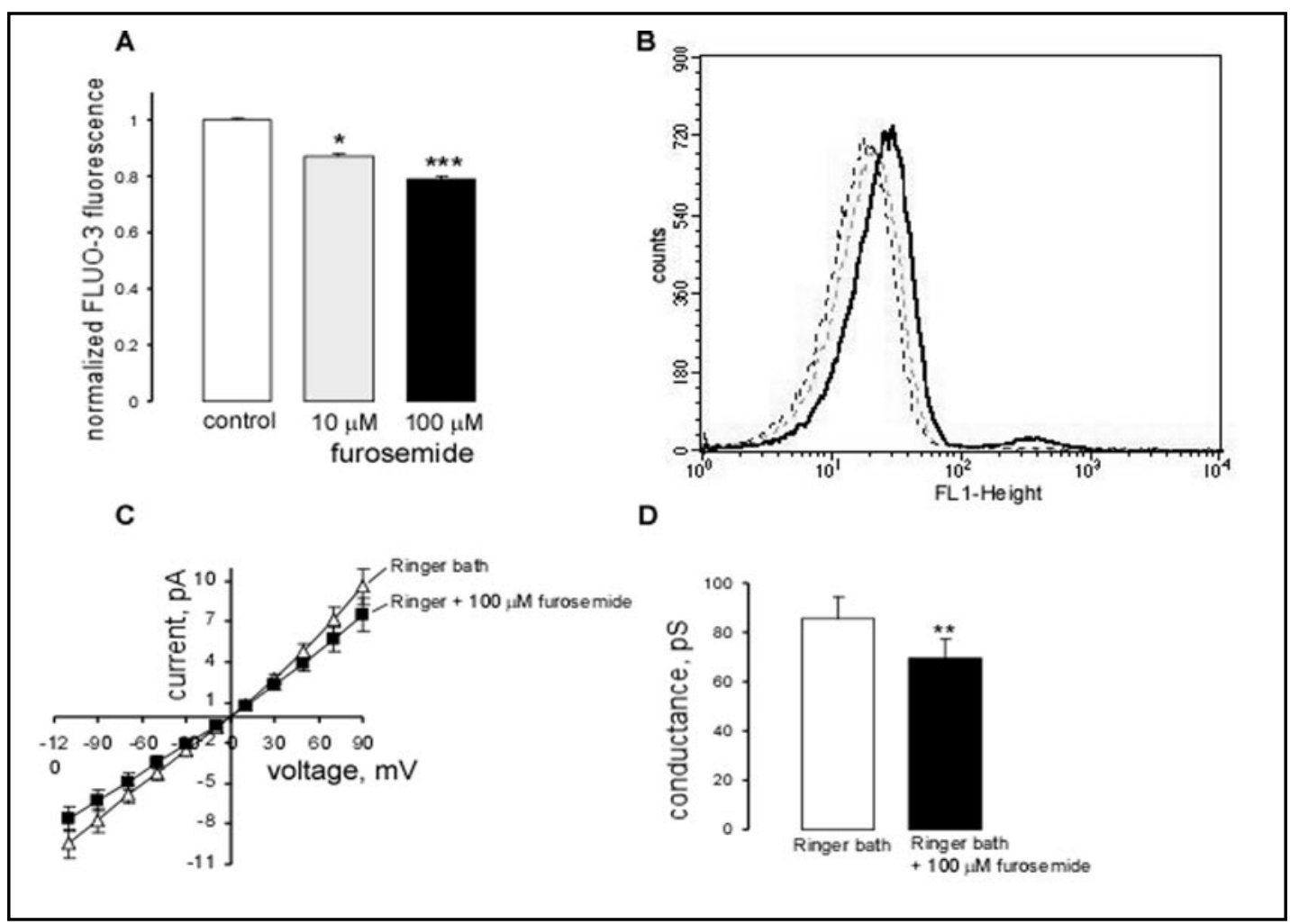

Fig. 1. Short exposure to furosemide reduces $\left[\mathrm{Ca}^{2+}\right]_{\mathrm{i}}$ and inhibits cation conductance in human erythrocytes. A. Arithmetic means \pm SEM of normalized Fluo-3 fluorescence, reflecting cytosolic $\mathrm{Ca}^{2+}$ activity $\left(\left[\mathrm{Ca}^{2+}\right]_{\mathrm{i}}\right)$, of human erythrocytes (white bar, $\mathrm{n}=11$ ) exposed for a short time ( $45 \mathrm{~min}$ ) to $10 \mu \mathrm{M}$ furosemide (grey bar, $\mathrm{n}=$ 12) and $100 \mu \mathrm{M}$ furosemide (black bar, $\mathrm{n}=12)$. ${ }^{*}$ and ${ }^{* *}$ indicate significant difference from control $(\mathrm{p}<0.05$ and 0.01 respectively; t-test). B. Histogram of Fluo-3 fluorescence in a representative experiment of human erythrocytes exposed $45 \mathrm{~min}$ to Ringer bath solution (solid line), and to $10 \mu \mathrm{M}$ furosemide (dotted line) or $100 \mu \mathrm{M}$ furosemide (dashed line) added to Ringer bath solution. C. Arithmetic means $( \pm$ SEM, $n=7)$ of the current as a function of voltage (I/V relationship) recorded in $\mathrm{NaCl}$ Ringer bath solution prior to (open circles) and following (closed circles) acute application of $100 \mu \mathrm{M}$ furosemide in $\mathrm{NaCl}$ Ringer bath solution. D. Arithmetic means $( \pm$ SEM, $n=7$ ) of the conductance (as calculated for the inward currents by linear regression) prior to (white bar) and following (black bar) acute application of $100 \mu \mathrm{M}$ furosemide in $\mathrm{NaCl}$ Ringer bath solution. ${ }^{* *}$ indicates significant difference from control ( $\mathrm{p} \leq 0.01$; paired t-test).

Statistics

Data are expressed as arithmetic means \pm SEM and paired two-tailed t-test or ANOVA were employed as appropriate, $\mathrm{p}<0.05$ was considered statistically significant.

\section{Results}

We first examined, whether a short incubation $\left(45 \mathrm{~min}\right.$ at $\left.37^{\circ} \mathrm{C}\right)$ with furosemide resulted in a decline of cytosolic $\mathrm{Ca}^{2+}$ activity $\left(\left[\mathrm{Ca}^{2+}\right]_{\mathrm{i}}\right)$ in human erythrocytes. As apparent from Fluo3 fluorescence (Fig. 1A, B), short exposure to furosemide (10 and $100 \mu \mathrm{M})$ indeed reduced in a concentration-dependent manner the basal levels of $\left[\mathrm{Ca}^{2+}\right]_{\mathrm{i}}$ in erythrocytes of healthy donors. Whole-cell patch-clamp experiments confirmed the inhibitory effect of furosemide on the cation conductance in human erythrocytes. Acute application of $100 \mu \mathrm{M}$ furosemide dissolved in $\mathrm{NaCl}$ Ringer bath solution had a slight but statistically significant lowering effect on the cation conductance (Fig. 1C, D). 


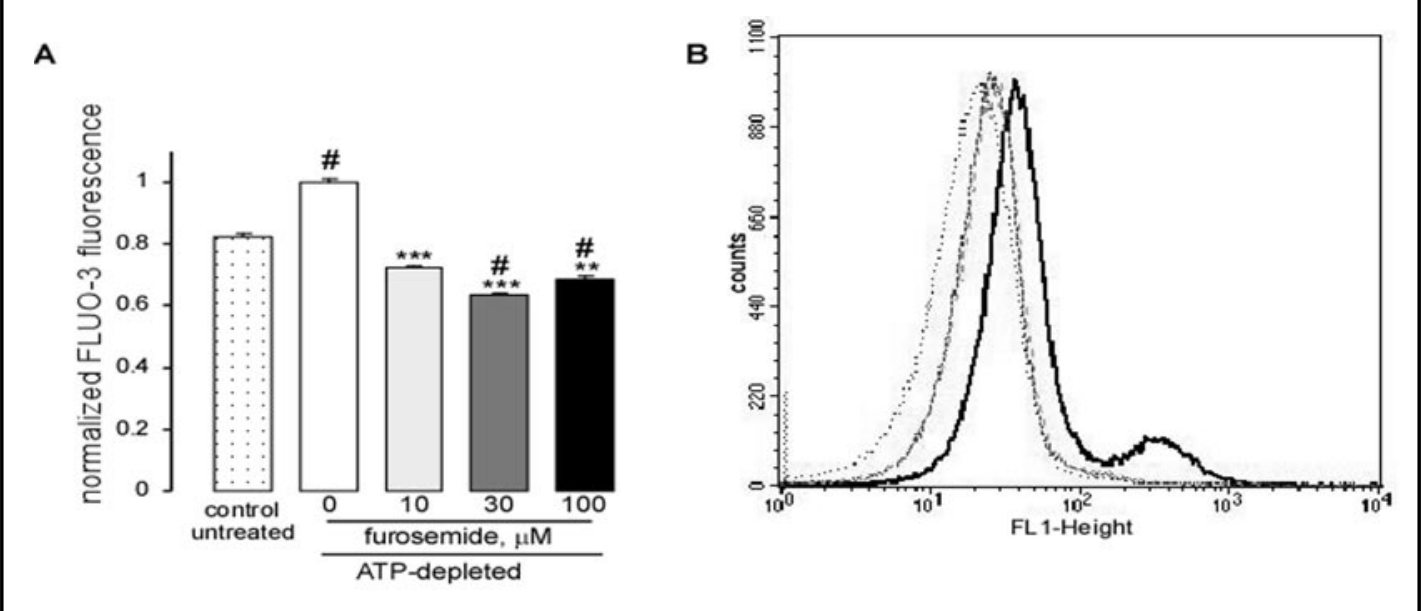

Fig. 2. Effect of furosemide $(10 \mu \mathrm{M}, 30 \mu \mathrm{M}$ and $100 \mu \mathrm{M})$ on $\left[\mathrm{Ca}^{2+}\right]_{\mathrm{i}}$ in metabolically ATP-depleted human erythrocytes. A. Arithmetic means \pm SEM of normalized Fluo-3 fluorescence reflecting cytosolic $\mathrm{Ca}^{2+}$ activity $\left(\left[\mathrm{Ca}^{2+}\right]_{\mathrm{i}}\right)$, of cells without ATP depletion (dotted bar, $\mathrm{n}=11$ ), and after 3-7 $\mathrm{h}$ incubation with ATP-depletion medium ( $6 \mathrm{mM}$ inosine, $6 \mathrm{mM}$ iodoacetic acid) in the absence (white bar, $\mathrm{n}=12$ ) and presence of $10 \mu \mathrm{M}$ furosemide (light grey bar, $\mathrm{n}=8$ ), $30 \mu \mathrm{M}$ furosemide (dark grey bar, $\mathrm{n}=4$ ) or $100 \mu \mathrm{M}$ furosemide (black bar, $\mathrm{n}=8)$. ${ }^{* *}$ and ${ }^{* * *}$ indicate significant difference from ATP-depleted cells in the absence of furosemide ( $p<0.01$ and 0.001 , respectively). \# indicates significant difference from control cells without ATP depletion $(\mathrm{p}<0.05$; ANOVA). B. Histogram of Fluo-3 fluorescence in a representative experiment with metabolically ATP-depleted human erythrocytes in $\mathrm{Ca}^{2+}$-containing ATP-depletion medium in the absence (solid line), or presence of $10 \mu \mathrm{M}, 30 \mu \mathrm{M}$ and $100 \mathrm{mM}$ furosemide (dotted and dashed lines respectively).

Since ATP-depletion triggers eryptosis, the next series of experiments explored the effect of furosemide on metabolically (ATP-depleted) cells. Similar to what was observed in energy replete cells, furosemide significantly decreased $\left[\mathrm{Ca}^{2+}\right]_{\mathrm{i}}$ in ATP-depleted cells (Fig. 2 A, B).

ATP-depletion is assumed to activate the non-selective voltage-independent cation channels. As shown in Fig. 3 (Fig. 3 A, B, E), ATP depletion indeed significantly increased the conductance of all tested cations $\left(\mathrm{Na}^{+}, \mathrm{Ca}^{2+}\right.$ and $\left.\mathrm{NMDG}^{+}\right)$. In contrast, ATP depletion did not significantly increase the conductance in the presence of furosemide (30 and $100 \mu \mathrm{M}$ ). In the presence of furosemide, the conductance of ATP depleted cells was not significantly different from control cells suggesting an inhibitory effect of furosemide on non-selective cation channels.

Since increase in $\left[\mathrm{Ca}^{2+}\right]_{\mathrm{i}}$ is known to stimulate cell membrane scrambling with subsequent phosphatidylserine exposure, additional experiments were performed to elucidate the effect of furosemide on annexin- $\mathrm{V}$ binding, which reflects phosphatidylserine exposure at the cell surface. As shown in Fig. 4, ATP depletion enhanced annexin V binding, an effect significantly lowered by furosemide $(10,30,100 \mu \mathrm{M})$ added to ATP-depleting medium.

A further series of experiments explored the effect of furosemide on the known stimulating effect of oxidative stress on cation channel activity, $\left[\mathrm{Ca}^{2+}\right]_{i}$ and cell membrane scrambling. As a result, oxidative stress induced by addition of high $(1 \mathrm{mM})$ or moderate $(0.1$ and $0.3 \mathrm{mM}$ ) concentrations of t-BHP significantly increased $\left[\mathrm{Ca}^{2+}\right]_{i}$, an effect significantly blunted by furosemide (10, 30 and $100 \mu \mathrm{M}$ ) (see Fig. 5).

In acute experiments high $(1 \mathrm{mM})$ concentrations of t-BHP were required to appreciably increase the cation conductance in patch-clamp experiments. Similarly, only high $(100 \mu \mathrm{M})$ concentrations of furosemide were tested, as according to flow cytometric experiments they had strong inhibitory effects on $\mathrm{Ca}^{2+}$ influx in oxidized cells. The exposure of erythrocytes 


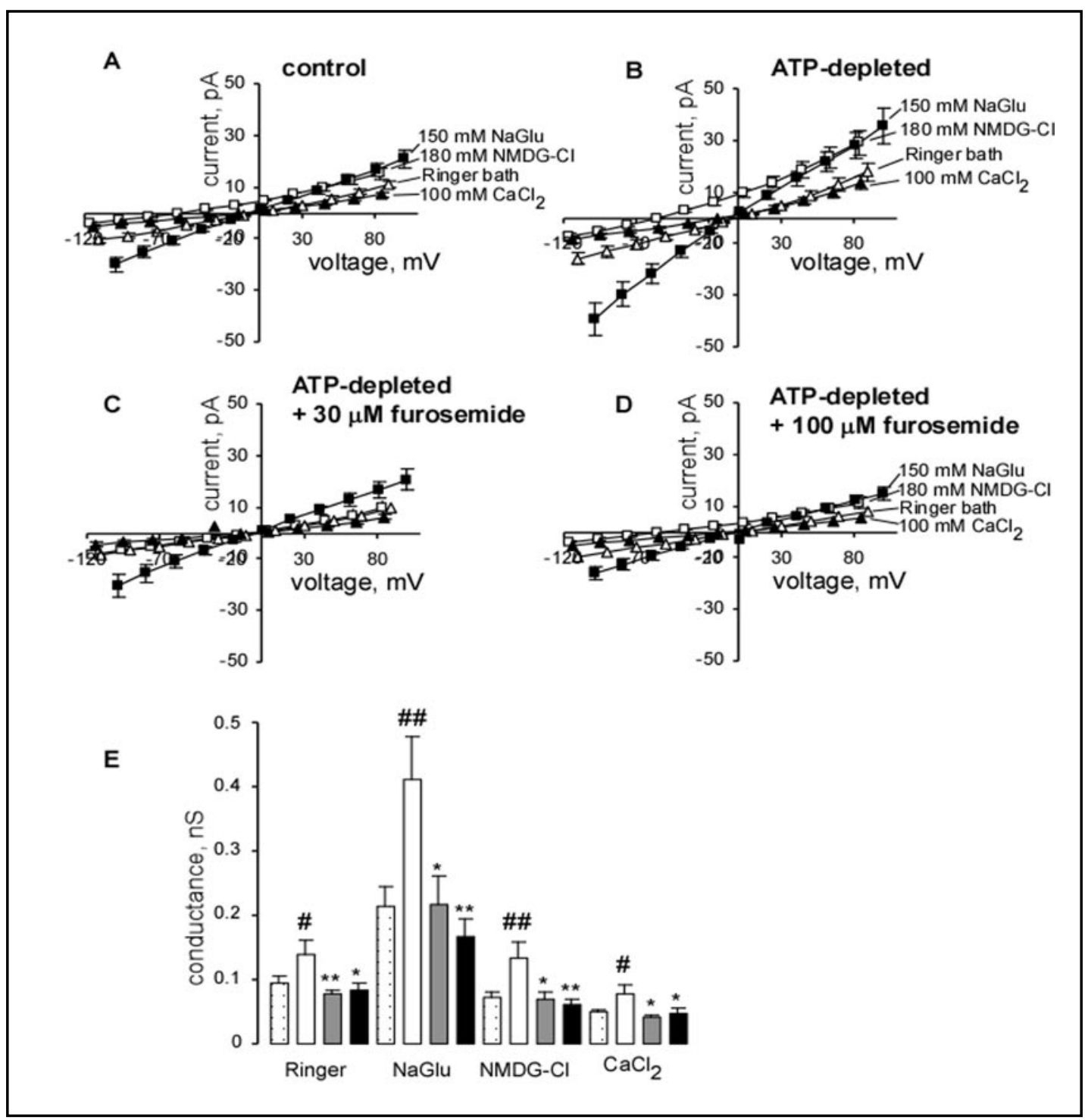

Fig. 3. Furosemide blocks non-selective cation conductance in metabolically ATP-depleted human erythrocytes. A. Arithmetic means $( \pm \mathrm{SEM}, \mathrm{n}=18$ ) of the current as a function of voltage (I/V relationship), recorded with Na-gluconate pipette solution, in human erythrocytes (control) suspended in $\mathrm{NaCl} \mathrm{Ringer} \mathrm{bath}$ solution (open triangles), $150 \mathrm{mM}$ Na-gluconate bath solution (closed squares), $100 \mathrm{mM} \mathrm{CaCl}_{2}$ bath solution (closed triangles) and $180 \mathrm{mM} \mathrm{NMDG-Cl} \mathrm{bath} \mathrm{solution} \mathrm{(open} \mathrm{squares).} \mathrm{B.} \mathrm{Arithmetic} \mathrm{means}( \pm \mathrm{SEM}, \mathrm{n}=10)$ of the current as a function of voltage (I/V relationship), recorded with Na-gluconate pipette solution, in metabolically ATP-depleted human erythrocytes suspended in $\mathrm{NaCl}$ Ringer bath solution (open triangles), $150 \mathrm{mM}$ Na-gluconate bath solution (closed squares), $100 \mathrm{mM} \mathrm{CaCl}_{2}$ bath solution (closed triangles) and $180 \mathrm{mM}$ NMDG-Cl bath solution (open squares). C. As in B. in the presence of $30 \mu \mathrm{M}$ furosemide in the ATPdepleting medium, NaCl Ringer, $150 \mathrm{mM}$ Na-gluconate, $100 \mathrm{mM} \mathrm{CaCl}$ and $180 \mathrm{mM} \mathrm{NMDG-Cl}$ bath solutions $(\mathrm{n}=12)$. D. As in B. in the presence of $100 \mu \mathrm{M}$ furosemide in the ATP-depleting medium, NaCl Ringer, 150 mM Na-gluconate, $100 \mathrm{mM} \mathrm{CaCl}_{2}$ and $180 \mathrm{mM} \mathrm{NMDG-Cl}$ bath solutions $(\mathrm{n}=15)$. E. Arithmetic means $( \pm$ SEM, $n=10 \div 18$ ) of the conductance (as calculated for the inward currents by linear regression) in control cells without ATP depletion (dotted bars), ATP-depleted cells in the absence (white bars) and presence of $30 \mu \mathrm{M}$ furosemide (grey bars) and $100 \mu \mathrm{M}$ furosemide (black bars) suspended in NaCl Ringer, $150 \mathrm{mM}$ Na-gluconate, $100 \mathrm{mM} \mathrm{CaCl}_{2}$ and $180 \mathrm{mM} \mathrm{NMDG-Cl}$ bath solutions. ${ }^{*}$ and ${ }^{* *}$ indicate significant difference from ATP-depleted cells without furosemide ( $\mathrm{p} \leq 0.05$ and 0.01 , respectively), \# and \#\# indicate significant difference from control cells without ATP depletion ( $\mathrm{p} \leq 0.05$ and 0.01 , respectively; ANOVA). 


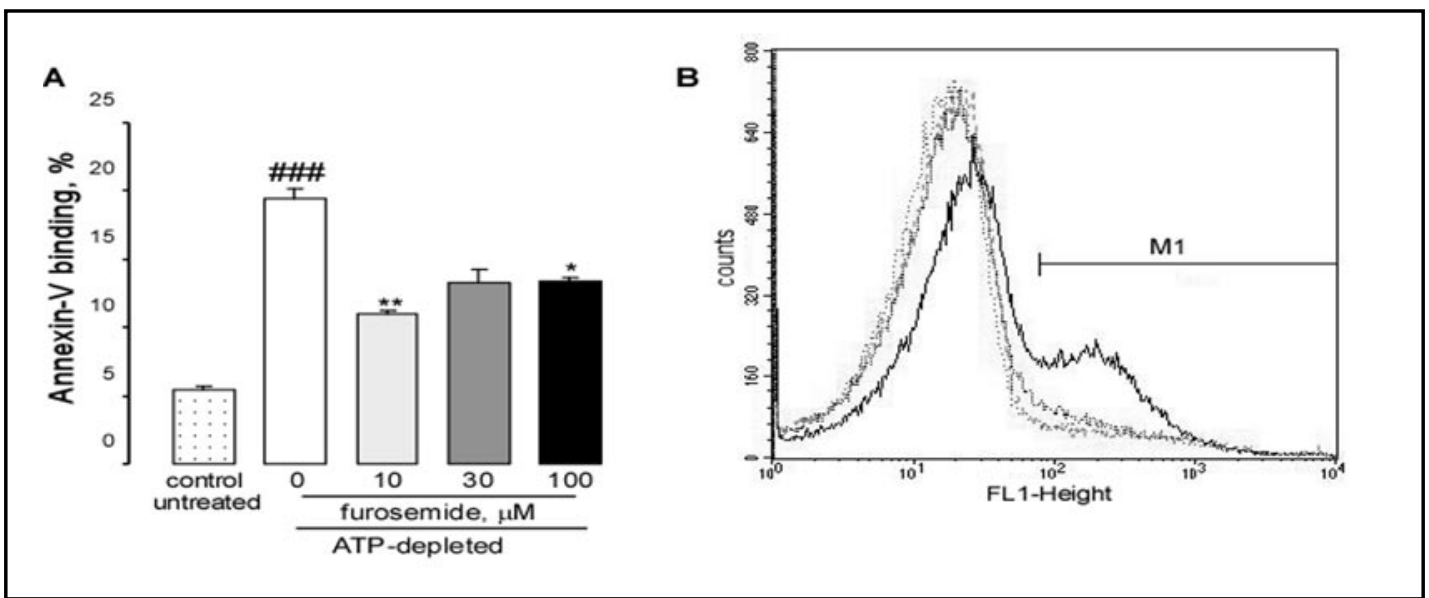

Fig. 4. Furosemide $(10 \mu \mathrm{M}, 30 \mu \mathrm{M}$ and $100 \mu \mathrm{M})$ blunts PS-exposure in ATP-depleted cells. A. Arithmetic means \pm SEM of normalized annexin V fluorescence of control cells without ATP depletion (dotted bar, $n$ = 3) and cells after 3-7 $\mathrm{h}$ incubation with ATP-depleting medium in the absence (white bar, $\mathrm{n}=3$ ) and presence of $10 \mu \mathrm{M}$ furosemide (light grey bar, $\mathrm{n}=6$ ), $30 \mu \mathrm{M}$ furosemide (dark grey bar, $\mathrm{n}=6$ ), or $100 \mu \mathrm{M}$ furosemide (black bar, $\mathrm{n}=6$ ). ${ }^{*}$ and ${ }^{* *}$ indicate significant difference from the ATP-depleted cells in the absence of furosemide ( $\mathrm{p}<0.05$ and 0.01 , respectively) and \#\#\# indicates significant difference from control cells without ATP depletion $(\mathrm{p}<0.001$; ANOVA). B. Histogram of annexin V-binding in a representative experiment with metabolically ATP-depleted human erythrocytes in $\mathrm{Ca}^{2+}$-containing ATP-depletion medium in the absence (solid line), or presence of $10 \mu \mathrm{M}, 30 \mu \mathrm{M}$ and $100 \mu \mathrm{M}$ furosemide (dotted and dashed lines respectively).

to Ringer bath solution containing $1 \mathrm{mM}$ t-BHP increased the cation conductance due to activation of non-selective cation channels, an effect significantly inhibited by furosemide (Fig. 6).

Oxidative stress (0.3 $\mathrm{mM}$ t-BHP) further increased annexin-V binding and thus phosphatidylserine exposure, an effect again significantly blunted in the presence of furosemide (10, 30 and $100 \mu \mathrm{M})$ (Fig. 7).

\section{Discussion}

The present study discloses a novel anti-eryptotic effect of the clinically widely used loop diuretic furosemide. At therapeutic serum concentrations (10 - 30 $\mu \mathrm{M}$ furosemide) and at concentrations $(100 \mu \mathrm{M})$ used for inhibition of ion channels activated by Plasmodium falciparum infection of human erythrocytes [16-18] furosemide inhibited $\mathrm{Ca}^{2+}$ permeable nonselective cation channels, thus decreasing cytosolic $\mathrm{Ca}^{2+}$ activity $\left(\left[\mathrm{Ca}^{2+}\right]_{\mathrm{i}}\right)$ and counteracting eryptosis of human erythrocytes.

The decrease in $\left[\mathrm{Ca}^{2+}\right]_{\mathrm{i}}$ upon loop diuretics treatment was supposed to be due to blockage of the $\mathrm{Na}^{+}, \mathrm{K}^{+}, 2 \mathrm{Cl}^{-}$cotransporter. Van Mil et al. [67] showed that under physiological conditions the activity of the $\mathrm{Na}^{+}, \mathrm{K}^{+}, 2 \mathrm{Cl}^{-}$cotransporter accumulates $\mathrm{Cl}^{-}$in the cells above equilibrium resulting in depolarisation and increases of $\mathrm{Ca}^{2+}$ influx via L-type $\mathrm{Ca}^{2+}$ channels. Diuretic therapy with furosemide was further shown to increase the activity of the $\mathrm{Na}^{+} / \mathrm{Ca}^{2+}$ exchanger (NCX) which could also modify the basal level of $\left[\mathrm{Ca}^{2+}\right]_{\mathrm{i}}[28]$.

Neither NCX nor voltage-dependent $\mathrm{Ca}^{2+}$ channels have been detected in human erythrocytes by patch-clamp experiments. Channels revealed by patch-clamp technique in human erythrocytes exposed to physiological saline are non-selective cation channels with low whole-cell cation conductance $(<100 \mathrm{pS})$ and activated upon $\mathrm{Cl}^{-}$removal, oxidative stress and osmotic shock [60]. A number of different non-selective cation channels could contribute to 


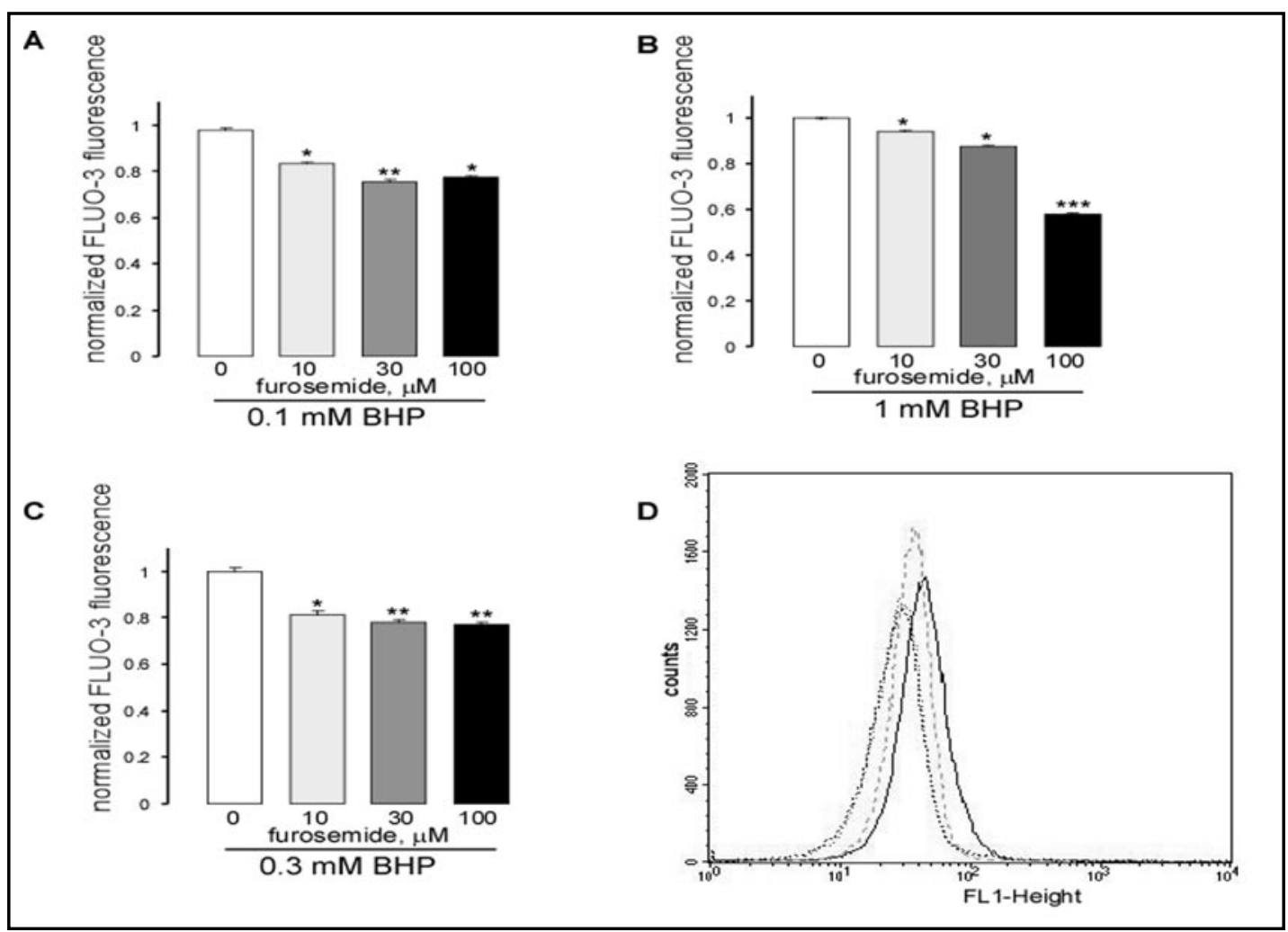

Fig. 5. Furosemide $(10 \mu \mathrm{M}, 30 \mu \mathrm{M}$ and $100 \mu \mathrm{M})$ inhibits $\mathrm{Ca}^{2+}$ uptake in t-BHP $(0.1 \mathrm{mM}, 0.3 \mathrm{mM}$ and $1 \mathrm{mM})$ treated human erythrocytes. A. Arithmetic means \pm SEM of normalized Fluo-3 fluorescence of human erythrocytes exposed for a short time $\left(45 \mathrm{~min}, 37^{\circ} \mathrm{C}\right)$ to $0.1 \mathrm{mM} \mathrm{t}-\mathrm{BHP}$ in the absence (white bar, $\mathrm{n}=3$ ) and presence of $10 \mu \mathrm{M}, 30 \mu \mathrm{M}$ and $100 \mu \mathrm{M}$ furosemide (light grey, dark grey and black bars, respectively $\mathrm{n}=3$ each). * and ** indicate significant difference from control ( $\mathrm{p}<0.05$ and 0.01 respectively; $\mathrm{t}$-test). B. Arithmetic means \pm SEM of normalized Fluo-3 fluorescence of human erythrocytes exposed for a short time (15 min, $37^{\circ} \mathrm{C}$ ) to $1 \mathrm{mM} \mathrm{t}-\mathrm{BHP}$ in the absence (white bar, $\mathrm{n}=10$ ) and presence of $10 \mu \mathrm{M}$ furosemide (light grey bar, $\mathrm{n}$ $=8$ ), $30 \mu \mathrm{M}$ furosemide (dark grey bar, $\mathrm{n}=6$ ) and $100 \mu \mathrm{M}$ furosemide (black bars, $\mathrm{n}=3$ ) respectively. * and $* * *$ indicate significant difference from control ( $\mathrm{p}<0.05$ and 0.001 , respectively; t-test). C. Arithmetic means \pm SEM of normalized Fluo-3 fluorescence of human erythrocytes exposed for a short time $\left(20 \mathrm{~min}, 37^{\circ} \mathrm{C}\right)$ to $0.1 \mathrm{mM} \mathrm{t}$-BHP in the absence (white bar, $\mathrm{n}=6$ ) and presence of $10 \mu \mathrm{M}, 30 \mu \mathrm{M}$ and $100 \mu \mathrm{M}$ furosemide (light grey, dark grey and black bars, respectively, $\mathrm{n}=6$ each). ${ }^{*}$ and ${ }^{* *}$ indicate significant difference from control ( $p<0.05$ and 0.01 respectively; t-test). D. Histogram of Fluo-3 fluorescence in a representative experiment with t-BHP treated human erythrocytes in $\mathrm{Ca}^{2+}$-containing Ringer bath solution in the absence (solid line), or presence of $10 \mu \mathrm{M}, 30 \mu \mathrm{M}$ and $100 \mu \mathrm{M}$ furosemide (dashed or dotted lines respectively).

the total cation conductance observed in erythrocytes. The presence of TRPC3/6/7 channels was confirmed by Western blotting [61]. Most recent data demonstrated the existence of NMDA receptors in rat [62] as well as AMPA receptors [31] and endothelin-B receptors [68] in human erythrocytes.

The whole-cell patch-clamp experiments performed in the present study revealed the absence of voltage-dependence of the cation channels and demonstrated that the channels are blocked by furosemide. They further show that the furosemide sensitive cation channels are induced by ATP-depletion and permeable to all cations tested $\left(\mathrm{Na}^{+}, \mathrm{Ca}^{2+}, \mathrm{NMDG}^{+}\right)$. The observation suggests that the loop diuretic furosemide exerts its effect on $\left[\mathrm{Ca}^{2+}\right]_{\mathrm{i}}$ in erythrocytes of healthy donors by inhibiting those non-selective cation channels. The fact that furosemide effectively inhibited non-selective cation conductance induced by ATP-depletion, oxidative 

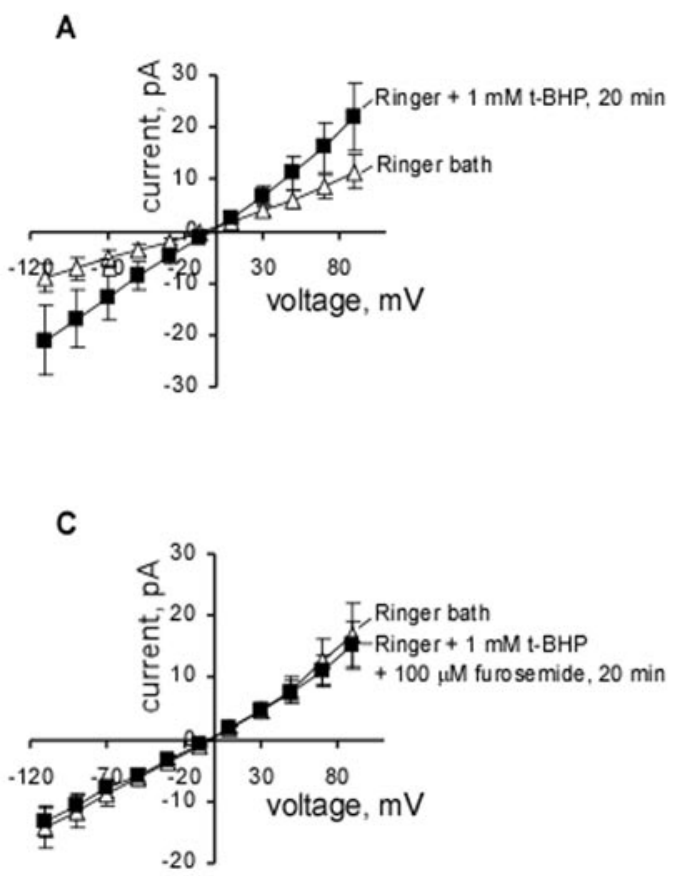

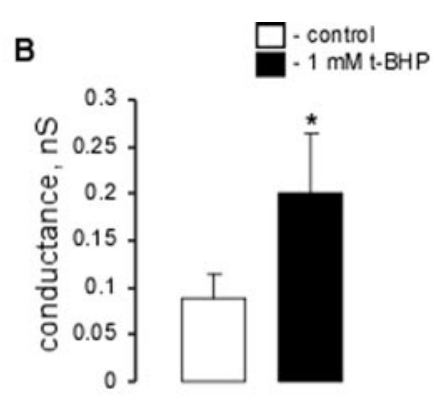

D

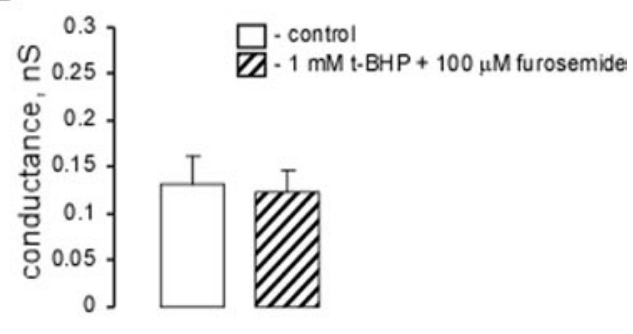

Fig. 6. Furosemide blocks cation conductance increase due to oxidative stress. A. Arithmetic means ( \pm SEM, $n=6)$ of the current as a function of voltage (I/V relationship) recorded in control cells in NaCl Ringer bath solution prior to (open circles) and after (open squares) acute application (20 min) of 1mM t-BHP in Ringer bath solution. B. Arithmetic means $( \pm \operatorname{SEM}, \mathrm{n}=6)$ of the conductance (as calculated for the inward currents by linear regression) in control cells prior to (white bar), and after (black bar) acute application of $1 \mathrm{mM}$ t-BHP in Ringer bath solution. * indicates significant difference from control ( $\mathrm{p} \leq 0.05$; paired t-test). C. As in A. in the presence of $100 \mu \mathrm{M}$ furosemide in the $\mathrm{NaCl}$ Ringer bath solution ( $=7)$. D. As in B. in the presence of $100 \mu \mathrm{M}$ furosemide in the $\mathrm{NaCl}$ Ringer bath solution (hatched bar, $\mathrm{n}=7$ ).
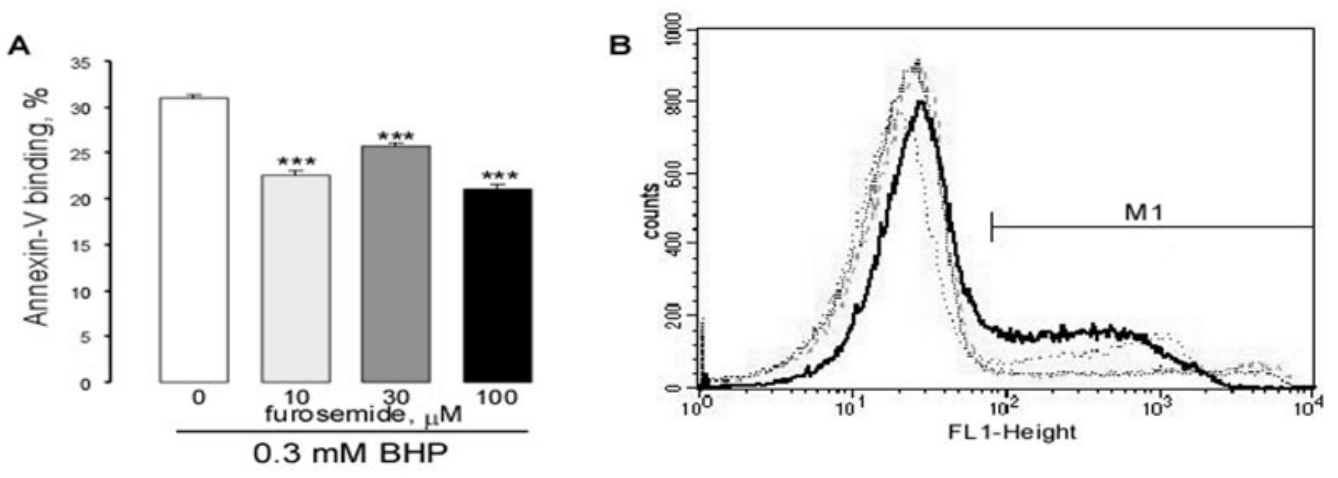

Fig. 7. Furosemide blunts PS-exposure in human erythrocytes treated with t-BHP. A. Arithmetic means \pm SEM of normalized annexin $V$ fluorescence of the cells treated with $0.3 \mathrm{mM} \mathrm{t}-\mathrm{BHP}\left(20 \mathrm{~min}, 37^{\circ} \mathrm{C}\right)$ in the absence (white bar, $n=6$ ) and presence of $10 \mu \mathrm{M}$ furosemide (light grey bar, $n=6$ ), $30 \mu \mathrm{M}$ furosemide (dark grey bar, $\mathrm{n}=3$ ), or $100 \mu \mathrm{M}$ furosemide (black bar, $\mathrm{n}=6$ ). ${ }^{* * *}$ indicates significant difference from control $(\mathrm{p}<0.001$, t-test). B. Histogram of annexin V-binding in a representative experiment with $0.3 \mathrm{mM}$ t-BHP treated cells. Solid line corresponds to control t-BHP treated cells while dashed and dotted lines show the cells oxidized in the presence of $10 \mu \mathrm{M}, 30 \mu \mathrm{M}$ and $100 \mu \mathrm{M}$ furosemide respectively. 
stress and $\mathrm{Cl}^{-}$removal allows us to assume the involvement of the non-selective channels described earlier [60]. At the same time, the experiments showed that acute application of furosemide dissolved in $\mathrm{Cl}^{-}$containing bath medium also reduced the cation conductance and lowered basal $\left[\mathrm{Ca}^{2+}\right]_{i}$, an observation possibly pointing to inhibition of another type of voltage-independent cation channel not requiring $\mathrm{Cl}^{-}$removal for activation.

Obviously, the inhibitory effect of furosemide on non-selective cation conductance does not result from blockage of electroneutral $\mathrm{Na}^{+}, \mathrm{K}^{+}, 2 \mathrm{Cl}^{-}$cotransporter activity. The present observations do not, however, define the exact mechanism of action. In theory, furosemide may inhibit the channel directly or by interference with some regulating mechanism. Furosemide was shown to enhance cAMP-phosphodiesterase activity that resulted in a decrease of cAMP concentration [10]. The members of TRPC channel family (TRPC3/4/5/6) have consensus PKA phosphorylation sites [69]. TRPC6 channels (that are also present in human erythrocytes [61]) are phosphorylated by PKA and associated with other cAMPkinase substrates [70]. Thus, at least in theory, the decline in $\left[\mathrm{Ca}^{2+}\right]_{\mathrm{i}}$ and the non-selective cation channels activity in furosemide-treated human erythrocytes could be due to PKA downregulation.

Besides affecting PKA and thus non-selective cation channels activity cAMP could be directly involved in the anti-eryptotic effect of furosemide. It is known that Raf/MEK/ERK signaling may result in the induction or arrest of cell cycle progression, as well as apoptosis [71]. cAMP has been shown to activate TRPC6 channels via PI3K-PKB-MEK-ERK1/2signaling pathway [72]. At the same time, activation of RAF/MEK/ERK pathway through RAS by calcium ionophore calcimycin (A23187) was shown to induce apoptosis in ocular lens epithelial cells [73]. Furosemide inhibits RAF/MEK/ERK phosphorylation in Balb/c 3T3 fibroblasts [9]. Thus, in theory, the anti-eryptotic effect of furosemide observed in our study might involve the MAPK pathway.

In conclusion, we show for the first time that the loop diuretic furosemide - applied at micromolar concentrations $(10-100 \mu \mathrm{M})$ - effectively blocks the non-selective cation channels and has an anti-eryptotic effect in human erythrocytes.

\section{References}

1 Banks MI, Li TB, Pearce RA: The synaptic basis of GABAA,slow. J Neurosci 1998;18:1305-1317.

2 Bank N: Physiological basis of diuretic action. Annu Rev Med 1968;19:103-118.

- Greger R: Ion transport mechanisms in thick ascending limb of Henle's loop of mammalian nephron. Physiol Rev 1985;65:760-797.

4 Hattori T, Wang PL: Involvement of $\mathrm{Na}^{+}-\mathrm{K}^{+}-2 \mathrm{Cl}^{-}$cotransporters in hypertonicity-induced rise in intracellular calcium concentration. Int J Neurosci 2006;116:1501-1507.

5 Kim JA, Kang YY, Lee YS: Activation of $\mathrm{Na}^{+}, \mathrm{K}^{+}, \mathrm{Cl}^{-}$-cotransport mediates intracellular $\mathrm{Ca}^{2+}$ increase and apoptosis induced by Pinacidil in HepG2 human hepatoblastoma cells. Biochem Biophys Res Commun 2001;281:511-519.

-6 Wiley JS, Cooper RA: A furosemide-sensitive cotransport of sodium plus potassium in the human red cell. J Clin Invest 1974;53:745-755.

7 Martin LA, Wei DS, Alger BE: Heterogeneous susceptibility of GABA(A) receptor-mediated IPSCs to depolarization-induced suppression of inhibition in rat hippocampus. J Physiol 2001;532:685-700.

8 Aravindan N, Aravindan S, Riedel BJ, Weng HR, Shaw AD: Furosemide prevents apoptosis and associated gene expression in a rat model of surgical ischemic acute renal failure. Ren Fail 2007;29:399-407.

9 Panet R, Eliash M, Atlan $\mathrm{H}: \mathrm{Na}^{+} / \mathrm{K}^{+} / \mathrm{Cl}^{-}$cotransporter activates MAP-kinase cascade downstream to protein kinase C, and upstream to MEK. J Cell Physiol 2006;206:578-585.

10 Mozhayeva MG, Bagrov Y, Ostretsova IB, Gillespie JI: The effect of frusemide on oxytocin-induced contractions of the rat myometrium. Exp Physiol 1994;79:661-667. 


\section{Cellular Physiology Cell Physiol Biochem 2012;30:863-875 and Biochemistry

11 Kreydiyyeh SI: Cyclic AMP and furosemide stimulate the $\mathrm{Na}^{+}-\mathrm{K}^{+}$ATPase in isolated rat jejunal cells. Pharmacol Res 2000;41:179-185.

-12 Kribben A, Fritschka E, Sibold M, Fassbender M, Rothschild M, Distler A, Philipp T: Different effects of furosemide on alpha-adrenoceptors and on platelet aggregation in man. Klin Wochenschr 1988;66:624627.

13 Ozu M, Dorr RA, Teresa PM, Parisi M, Toriano R: Water flux through human aquaporin 1: inhibition by intracellular furosemide and maximal response with high osmotic gradients. Eur Biophys J 2011;40:737746.

14 Ford DA, Sharp JA, Rovetto MJ: Erythrocyte adenosine transport: effects of $\mathrm{Ca}^{2+}$ channel antagonists and ions. Am J Physiol 1985;248:H593-H598.

15 He Y, Ji W, Huang H: Effect of the Cation-Chloride Cotransporter Inhibitor Furosemide in a Rat Model of Postoperative Pain. Pain Med 2011;12:1427-1434.

-16 Duranton C, Huber SM, Tanneur V, Brand VB, Akkaya C, Shumilina EV, Sandu CD, Lang F: Organic osmolyte permeabilities of the malaria-induced anion conductances in human erythrocytes. J Gen Physiol 2004;123:417-426.

17 Staines HM, Ellory JC, Kirk K: Perturbation of the pump-leak balance for $\mathrm{Na}^{+}$and $\mathrm{K}^{+}$in malaria-infected erythrocytes. Am J Physiol Cell Physiol 2001;280:C1576-C1587.

18 Staines HM, Dee BC, O’Brien M, Lang HJ, Englert H, Horner HA, Ellory JC, Kirk K: Furosemide analogues as potent inhibitors of the new permeability pathways of Plasmodium falciparum-infected human erythrocytes. Mol Biochem Parasitol 2004;133:315-318.

-19 Gomez-Lazaro M, Galindo MF, Melero-Fernandez de Mera RM, Fernandez-Gomez FJ, Concannon CG, Segura MF, Comella JX, Prehn JH, Jordan J: Reactive oxygen species and p38 mitogen-activated protein kinase activate Bax to induce mitochondrial cytochrome c release and apoptosis in response to malonate. Mol Pharmacol 2007;71:736-743.

20 Karpinich NO, Tafani M, Rothman RJ, Russo MA, Farber JL: The course of etoposide-induced apoptosis from damage to DNA and p53 activation to mitochondrial release of cytochrome c. J Biol Chem 2002;277:1654716552.

-21 Yuengsrigul A, Chin TW, Nussbaum E: Immunosuppressive and cytotoxic effects of furosemide on human peripheral blood mononuclear cells. Ann Allergy Asthma Immunol 1999;83:559-566.

22 Kiely DG, Cargill RI, Lipworth BJ: Effects of frusemide and hypoxia on the pulmonary vascular bed in man. Br J Clin Pharmacol 1997;43:309-313.

23 Riordan JF: Angiotensin-I-converting enzyme and its relatives. Genome Biol 2003;4:225.

24 Zappulla D: Environmental stress, erythrocyte dysfunctions, inflammation, and the metabolic syndrome: adaptations to $\mathrm{CO}_{2}$ increases? J Cardiometab Syndr 2008;3:30-34.

25 Erne P, Bolli P, Burgisser E, Buhler FR: Correlation of platelet calcium with blood pressure. Effect of antihypertensive therapy. N Engl J Med 1984;310:1084-1088.

-26 Spieker C, Zidek W, Hacker W, Schmidt W, Vetter H: Assessment of intracellular sodium and calcium in essential hypertension during diuretic treatment. Arzneimittelforschung 1988;38:188-190.

-27 Zidek W, Karoff C, Baumgart P, Losse H, Fehske KJ, Hacker W, Vetter H: Intracellular sodium and calcium during antihypertensive treatment. Klin Wochenschr 1985;63 Suppl 3:147-149.

-28 Wei SK, McCurley JM, Hanlon SU, Haigney MC: Gender differences in Na/Ca exchanger current and betaadrenergic responsiveness in heart failure in pig myocytes. Ann N Y Acad Sci 2007;1099:183-189.

29 Lang F, Lang KS, Lang PA, Huber SM, Wieder T: Mechanisms and significance of eryptosis. Antioxid Redox Signal 2006;8:1183-1192.

-30 Lang F, Gulbins E, Lerche H, Huber SM, Kempe DS, Foller M: Eryptosis, a window to systemic disease. Cell Physiol Biochem 2008;22:373-380.

-31 Foller M, Bobbala D, Koka S, Huber SM, Gulbins E, Lang F: Suicide for survival--death of infected erythrocytes as a host mechanism to survive malaria. Cell Physiol Biochem 2009;24:133-140.

32 Birka C, Lang PA, Kempe DS, Hoefling L, Tanneur V, Duranton C, Nammi S, Henke G, Myssina S, Krikov M, Huber SM, Wieder T, Lang F: Enhanced susceptibility to erythrocyte "apoptosis" following phosphate depletion. Pflugers Arch 2004;448:471-477.

33 Bobbala D, Alesutan I, Foller M, Huber SM, Lang F: Effect of anandamide in Plasmodium Berghei-infected mice. Cell Physiol Biochem 2010;26:355-362. 
34 Kempe DS, Lang PA, Duranton C, Akel A, Lang KS, Huber SM, Wieder T, Lang F: Enhanced programmed cell death of iron-deficient erythrocytes. FASEB J 2006;20:368-370.

-35 Kempe DS, Akel A, Lang PA, Hermle T, Biswas R, Muresanu J, Friedrich B, Dreischer P, Wolz C, Schumacher U, Peschel A, Gotz F, Doring G, Wieder T, Gulbins E, Lang F: Suicidal erythrocyte death in sepsis. J Mol Med (Berl) 2007;85:273-281.

-36 Lang PA, Beringer O, Nicolay JP, Amon O, Kempe DS, Hermle T, Attanasio P, Akel A, Schafer R, Friedrich B, Risler T, Baur M, Olbricht CJ, Zimmerhackl LB, Zipfel PF, Wieder T, Lang F: Suicidal death of erythrocytes in recurrent hemolytic uremic syndrome. J Mol Med (Berl) 2006;84:378-388.

-37 Lang PA, Schenck M, Nicolay JP, Becker JU, Kempe DS, Lupescu A, Koka S, Eisele K, Klarl BA, Rubben H, Schmid KW, Mann K, Hildenbrand S, Hefter H, Huber SM, Wieder T, Erhardt A, Haussinger D, Gulbins E, Lang F: Liver cell death and anemia in Wilson disease involve acid sphingomyelinase and ceramide. Nat Med 2007;13:164-170.

38 Lang PA, Kasinathan RS, Brand VB, Duranton C, Lang C, Koka S, Shumilina E, Kempe DS, Tanneur V, Akel A, Lang KS, Foller M, Kun JF, Kremsner PG, Wesselborg S, Laufer S, Clemen CS, Herr C, Noegel AA, Wieder T, Gulbins E, Lang F, Huber SM: Accelerated clearance of Plasmodium-infected erythrocytes in sickle cell trait and annexin-A7 deficiency. Cell Physiol Biochem 2009;24:415-428.

39 Siraskar B, Ballal A, Bobbala D, Foller M, Lang F: Effect of amphotericin B on parasitemia and survival of plasmodium berghei-infected mice. Cell Physiol Biochem 2010;26:347-354.

40 Felder KM, Hoelzle K, Ritzmann M, Kilchling T, Schiele D, Heinritzi K, Groebel K, Hoelzle LE: Hemotrophic mycoplasmas induce programmed cell death in red blood cells. Cell Physiol Biochem 2011;27:557-564.

41 Bhavsar SK, Eberhard M, Bobbala D, Lang F: Monensin induced suicidal erythrocyte death. Cell Physiol Biochem 2010;25:745-752.

-42 Bhavsar SK, Bobbala D, Xuan NT, Foller M, Lang F: Stimulation of suicidal erythrocyte death by alpha-lipoic acid. Cell Physiol Biochem 2010;26:859-868.

43 Braun M, Foller M, Gulbins E, Lang F: Eryptosis triggered by bismuth. Biometals 2009;22:453-460.

44 Eberhard M, Ferlinz K, Alizzi K, Cacciato PM, Faggio C, Foller M, Lang F: FTY720-induced suicidal erythrocyte death. Cell Physiol Biochem 2010;26:761-766.

45 Gatidis S, Foller M, Lang F: Hemin-induced suicidal erythrocyte death. Ann Hematol 2009;88:721-726.

46 Mahmud H, Foller M, Lang F: Arsenic-induced suicidal erythrocyte death. Arch Toxicol 2009;83:107-113.

47 Mahmud H, Dalken B, Wels WS: Induction of programmed cell death in ErbB2/HER2-expressing cancer cells by targeted delivery of apoptosis-inducing factor. Mol Cancer Ther 2009;8:1526-1535.

-48 Bhavsar SK, Gu S, Bobbala D, Lang F: Janus kinase 3 is expressed in erythrocytes, phosphorylated upon energy depletion and involved in the regulation of suicidal erythrocyte death. Cell Physiol Biochem 2011;27:547-556.

49 Gatidis S, Zelenak C, Fajol A, Lang E, Jilani K, Michael D, Qadri SM, Lang F: p38 MAPK activation and function following osmotic shock of erythrocytes. Cell Physiol Biochem 2011;28:1279-1286.

50 Ghashghaeinia M, Toulany M, Saki M, Bobbala D, Fehrenbacher B, Rupec R, Rodemann HP, Ghoreschi K, Rocken M, Schaller M, Lang F, Wieder T: The NFKB pathway inhibitors Bay 11-7082 and parthenolide induce programmed cell death in anucleated Erythrocytes. Cell Physiol Biochem 2011;27:45-54.

-51 Lang E, Jilani K, Zelenak C, Pasham V, Bobbala D, Qadri SM, Lang F: Stimulation of suicidal erythrocyte death by benzethonium. Cell Physiol Biochem 2011;28:347-354.

-52 Qadri SM, Kucherenko Y, Zelenak C, Jilani K, Lang E, Lang F: Dicoumarol activates $\mathrm{Ca}^{2+}$-permeable cation channels triggering erythrocyte cell membrane scrambling. Cell Physiol Biochem 2011;28:857-864.

53 Qadri SM, Bauer J, Zelenak C, Mahmud H, Kucherenko Y, Lee SH, Ferlinz K, Lang F: Sphingosine but not sphingosine-1-phosphate stimulates suicidal erythrocyte death. Cell Physiol Biochem 2011;28:339-346.

54 Klarl BA, Lang PA, Kempe DS, Niemoeller OM, Akel A, Sobiesiak M, Eisele K, Podolski M, Huber SM, Wieder T, Lang F: Protein kinase C mediates erythrocyte "programmed cell death" following glucose depletion. Am J Physiol Cell Physiol 2006;290:C244-C253.

-55 Calderon-Salinas JV, Munoz-Reyes EG, Guerrero-Romero JF, Rodriguez-Moran M, Bracho-Riquelme RL, Carrera-Gracia MA, Quintanar-Escorza MA: Eryptosis and oxidative damage in type 2 diabetic mellitus patients with chronic kidney disease. Mol Cell Biochem 2011;357:171-179.

56 Hermle T, Shumilina E, Attanasio P, Akel A, Kempe DS, Lang PA, Podolski M, Gatz S, Bachmann R, Bachmann C, Abele H, Huber S, Wieder T, Lang F: Decreased cation channel activity and blunted channel-dependent eryptosis in neonatal erythrocytes. Am J Physiol Cell Physiol 2006;291:C710-C717. 
57 Baunbaek M, Bennekou P: Evidence for a random entry of $\mathrm{Ca}^{2+}$ into human red cells. Bioelectrochemistry 2008;73:145-150.

58 Bennekou P: The voltage-gated non-selective cation channel from human red cells is sensitive to acetylcholine. Biochim Biophys Acta 1993;1147:165-167.

-59 Kaestner L, Bollensdorff C, Bernhardt I: Non-selective voltage-activated cation channel in the human red blood cell membrane. Biochim Biophys Acta 1999;1417:9-15.

60 Huber SM, Gamper N, Lang F: Chloride conductance and volume-regulatory nonselective cation conductance in human red blood cell ghosts. Pflugers Arch 2001;441:551-558.

-61 Foller M, Kasinathan RS, Koka S, Lang C, Shumilina E, Birnbaumer L, Lang F, Huber SM: TRPC6 contributes to the $\mathrm{Ca}^{2+}$ leak of human erythrocytes. Cell Physiol Biochem 2008;21:183-192.

62 Makhro A, Wang J, Vogel J, Boldyrev AA, Gassmann M, Kaestner L, Bogdanova A: Functional NMDA receptors in rat erythrocytes. Am J Physiol Cell Physiol 2010;298:C1315-C1325.

63 Romero PJ, Romero EA, Mateu D, Hernandez C, Fernandez I: Voltage-dependent calcium channels in young and old human red cells. Cell Biochem Biophys 2006;46:265-276.

64 Margalho C, de Boer D, Gallardo E, Barroso M, Vieira DN: Determination of furosemide in whole blood using SPE and GC-EI-MS. J Anal Toxicol 2005;29:309-313.

65 Lew VL: On the ATP dependence of the $\mathrm{Ca}^{2+}$-induced increase in $\mathrm{K}^{+}$permeability observed in human red cells. Biochim Biophys Acta 1971;233:827-830.

66 Barry PH, Lynch JW: Liquid junction potentials and small cell effects in patch-clamp analysis. J Membr Biol 1991;121:101-117.

67 van Mil HG, Geukes Foppen RJ, Siegenbeek van Heukelom J: The influence of bumetanide on the membrane potential of mouse skeletal muscle cells in isotonic and hypertonic media. Br J Pharmacol 1997;120:39-44.

68 Foller M, Mahmud H, Qadri SM, Gu S, Braun M, Bobbala D, Hocher B, Lang F: Endothelin B receptor stimulation inhibits suicidal erythrocyte death. FASEB J 2010;24:3351-3359.

69 Tomic M, Kucka M, Kretschmannova K, Li S, Nesterova M, Stratakis CA, Stojilkovic SS: Role of nonselective cation channels in spontaneous and protein kinase A-stimulated calcium signaling in pituitary cells. Am J Physiol Endocrinol Metab 2011;301:E370-E379.

70 Hassock SR, Zhu MX, Trost C, Flockerzi V, Authi KS: Expression and role of TRPC proteins in human platelets: evidence that TRPC6 forms the store-independent calcium entry channel. Blood 2002;100:28012811.

71 Yang SH, Sharrocks AD, Whitmarsh AJ: Transcriptional regulation by the MAP kinase signaling cascades. Gene 2003;320:3-21.

72 Shen B, Kwan HY, Ma X, Wong CO, Du J, Huang Y, Yao X: cAMP activates TRPC6 channels via the phosphatidylinositol 3-kinase (PI3K)-protein kinase B (PKB)-mitogen-activated protein kinase kinase (MEK)-ERK1/2 signaling pathway. J Biol Chem 2011;286:19439-19445.

73 Li DW, Liu JP, Mao YW, Xiang H, Wang J, Ma WY, Dong Z, Pike HM, Brown RE, Reed JC: Calcium-activated RAF/MEK/ERK signaling pathway mediates p53-dependent apoptosis and is abrogated by alpha B-

crystallin through inhibition of RAS activation. Mol Biol Cell 2005;16:4437-4453. 